\title{
The effect of temperature on the preimaginal development of the Jewel beetle, Coraebus florentinus (Coleoptera: Buprestidae)
}

\author{
ANA M. CÁRDENAS and Patricia GALLARDO
}

Department of Zoology, Campus Rabanales, E-14071 University of Córdoba, Spain; e-mails: ba1cataa@uco.es; b42gatop@uco.es

Key words. Buprestidae, Coraebus florentinus, Jewel beetle, Quercus, temperature effect, preimaginal development

\begin{abstract}
Environmental degradation caused by climate change greatly affects the forest ecosystems of the Mediterranean region, in particular the sclerophyllous Quercus forests typical of central and southern Spain. An important pest that damages oak trees in this area is Coraebus florentinus (Herbst), a heliophilous and thermophilous insect whose survival could be favoured by the temperature increase associated with climate change. The main objective of this paper was to determine the effect of temperature on the duration and percentage survival of the preimaginal stage of $C$. florentinus and provide data for determining more precisely when to control for this pest by applying silvicultural techniques. The experiment included six treatments, with 25 branches infested with $C$. florentinus in each of the treatments, which were kept at different temperatures over the range $15-28^{\circ} \mathrm{C}$. The results clearly support the hypothesis that higher temperatures affect the post-larval development of $C$. florentinus by increasing the percentage survival and shortening the developmental time. In fact, partial correlations confirm that the highest percentages of emergence and survival were recorded when the developmental times were shortest, which occurred at the highest temperatures used. Despite the clear influence of temperature on the development of the preimaginal stage of $C$. florentinus, additional trials are required to accurately determine future trends in $C$. florentinus populations. Accordingly, it is necessary to develop monitoring programs in zones affected by $C$. florentinus and to apply scheduled management techniques that ensure the control of this species.
\end{abstract}

\section{INTRODUCTION}

Studies conducted over recent years on the responses of both fauna and flora at different levels of organisation, from species to ecosystems, have shown that climate change is having an effect on natural ecosystems (Walther et al., 2002). Climate change is having a negative effect on organisms and habitats, altering the composition of plant and animal communities and causing phenological asynchronies, which eventually lead to loss of biodiversity (DEFRA, 2010). This environmental degradation affects, though in unequal ways and to different degrees, the different habitats on the planet, including forest ecosystems (Maresi \& Salvadori, 2005; Pardos, 2006; Freer-Smith et al., 2007).

The greatest biodiversity in Europe is in the Mediterranean region (Cowling et al., 1996), and the ecosystem there is highly susceptible to environmental warming because of its transitional location between the Eurosiberian and the Saharo-Sindic climatic regions and the harshness of the environment such as frequent forest fires and droughts (Sánchez et al., 2004). The Iberian Peninsula, in particular, is a hot-spot of biodiversity (Medial \& Quézel, 1997), which is likely to be severely affected by climate change (Gómez-Campo \& Malato-Béliz, 1985; Benito et al., 2008). This vulnerability, which has been detected in different natural ecosystems, also affects the sclerophyllous oak forests typical of central and southern Spain (Benito et al., 2008).

The direct influence of climate on the species of oaks (Quercus) that form the mixed Mediterranean forest has been studied from different points of view, including chorological (Benito et al., 2008), eco-physiological (Gea-
Izquierdo et al., 2009; Patón et al., 2009) and phytosanitary (Navarro et al., 2007). However, other, more indirect and long-term, consequences should also be considered, such as forestalling the disturbing effects of climate change on herbivory and the activity of pathogens (Ayres \& Lombardero, 2000).

Increase in temperature affects phenology, life cycles and the distribution of phytophagous insects (Alexander, 2003), as well as the synchronization of insect-plant interactions (Buse \& Good, 1996; Bale et al., 2002). An increase in temperature may therefore favour the development of pests, intensifying their effects or widening their distribution.

An important pest that damages oak trees is Coraebus florentinus (Herbst) (Coleoptera: Buprestidae), which is xylophagous and damages the species of oak that make up the mixed Mediterranean forests. It is a primary parasite and is very harmful and restricted to various species of Quercus (Q. suber Linné, Q. ilex Linné, Q. robur Linné, $Q$. pubescens Willdenow, $Q$. cerris Linné, $Q$. coccifera Linné, $Q$. toza Linné, $Q$. pedunculata Ehrhart, $Q$. canariensis Willdenow, Q. faginea Lamarck and Q. sessiliflora Smith) (Schaefer, 1949; Zochi, 1953; Goidanich, 1954; Soria, 1990) and chestnut (Castanea sativa W. Miller); (Balachowsky, 1962).

C. florentinus is only found in those areas of Mediterranean forest where oaks predominate (Fig. 1): Spain, Portugal, France, Sardinia, Italy, Switzerland, Austria, the Czech Republic, former Yugoslavia, Romania and Bulgaria (Cobos, 1986). Solinas (1974) reports the occurrence of this species in North Africa and Tiberghien (1974) reports it in Tunisia. Although it is likely that this 


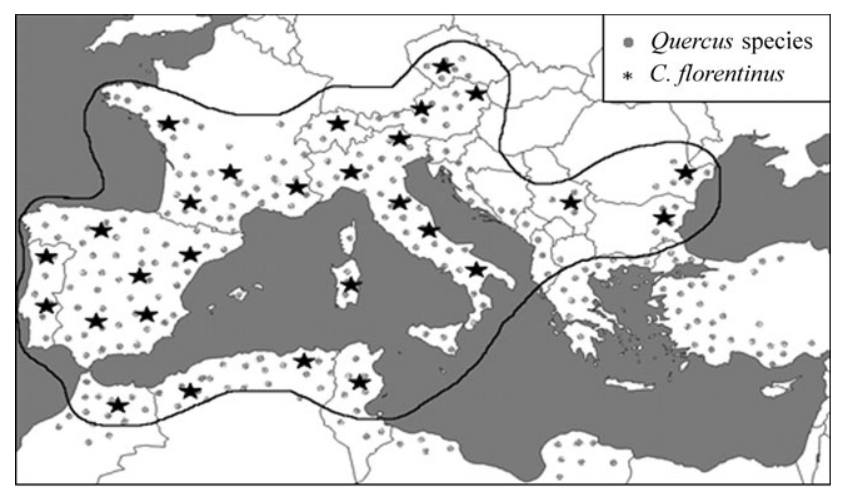

Fig. 1. Map showing the distribution of species of Quercus and Coraebus florentinus in the Mediterranean area. The black line defines the area where both species of Quercus and Coraebus florentinus co-occur.

species occurs in most of the Iberian Peninsula (Arnáiz et al., 2002), it primarily occurs in those areas where cork (Q. suber) and holm oaks (Q. ilex) are dominant (Bachiller et al., 1981).

The larvae of $C$. florentinus take two years to complete their development (Ceballos, 1974; Bachiller et al., 1981), but larval periods of three and even four years are recorded (Cecconi, 1924; Fernández de Cordova \& Cabezuelo, 1995). Adults emerge in early summer and feed on the leaves of their host plants (Soria, 1990). In early August, they mate and the female oviposits in small cracks in the bark of young branches ( 1 or 2 years old), usually one egg per branch. The eggs hatch within two weeks, the larvae pierce the bark and once inside a branch begin feeding and constructing long and wavy galleries towards the thicker basal zone of the branches until the larvae reaches the fifth instar. The fifth instar larvae continue boring galleries that spiral round the branch and interrupt sap flow, which cause the branch to dry out (Romanyk \& Cadahía, 1992). Once the sap flow to a branch ceases, the larva reverses its position and ascend upwards to build a pupation chamber, within which it complete its metamorphosis. Before entering into quiescence, the larvae drill a hole to the outside to facilitate the exit of the adults and then seal it with sawdust (Jurc et al., 2009). Damage caused by larvae of C. florentinus is easily identifiable (Montoya, 1988; Soria \& Ocete, 1993), and to date, the most effective method of controlling this species is to remove the damaged branches before the adults emerge (Evans et al., 2004).

The levels of infestation of oaks by this buprestid on the Iberian Peninsula have been assessed (Soria \& Ocete, 1993; Soria et al., 1994; Fernández de Cordova \& Cabezuelo, 1995; Rivas, 2000). Nevertheless, studies on its biology are scarce and have usually focused on the use of pheromones to control this pest (Rodrigo \& Herranz, 2006; Gemeno, 2007; Riba, 2008).

C. florentinus is a heliophilous and thermophilous insect (Cobos, 1986; Verdugo, 2005) that tends to colonize the warmer parts of a tree (south, southeast and southwest orientations) and the increase in its abundance from endemic to epidemic levels primarily depends on weather conditions, which can occasionally be very favourable for reproduction. For that reason, we proposed the working hypothesis that an increase in temperature will result in an increase in the abundance of $C$. florentinus.

Knowing the effect of temperature on the biology of this species would facilitate the development of a model for predicting its population dynamics and determining the precise time to implement control measures, particularly the selective pruning of branches. This action must be carried out prior to the emergence of the adults. This should result in the decrease in the number of breeding adults, which leads to a gradual decline in the abundance of subsequent generations and, therefore, the return of populations to endemic levels. As a result this xylophagous insect will cease to be a threat to the conservation of this forest ecosystem.

The main objective of this study was to determine the effect of temperature on the duration and survival of the preimaginal phase of $C$. florentinus in order to more precisely determine when to control this pest by means of silvicultural techniques.

This work is part of a larger study entitled "Study and Monitoring Plan of boring beetles from Quercus species" and was included as one of a set of compensation measures associated with the construction of the Breña II dam (92/43/EEC Directive Habitat of European Council for the conservation of natural habitats and wildlife).

\section{MATERIAL AND METHODS}

To study the effect of temperature on the development of the preimaginal stage of $C$. florentinus it was kept at six different temperatures. At each temperature, a group of 25 branches that showed clear symptoms of infestation with $C$. florentinus were selected in the field. The branches came from the area that was planned to be improved when the Breña II dam is constructed, which is located in the Natural Park of Sierra de Hornachuelos in the south of the Iberian Peninsula. This is an area of mixed Mediterranean forest in which oaks (mainly $Q$. suber and $Q$. ilex) are the dominant vegetation and there is a high incidence of damage caused by this buprestid.

Branches from oak trees were collected during April 2009, prior to the emergence of $C$. florentinus adults. Damaged branches were identified by visually searching the tops of oaks and locating terminal branches, which were mostly of medium size relative to the other branches in the tree tops, with leaves of a yellowish to reddish brown colour, contrasting with the green of the rest of the canopy (Romanyk \& Cadahia, 1992).

Branches were collected from $Q$. ilex ssp. ballota and $Q$. suber. To reduce the effect that differences between trees may have on the results only one branch was collected from each tree. The branches were collected from trees of different ages at different distances from one another. Considering all the trees in the study area it is estimated that both holm oak and cork trees are middle aged (average diameter $=43.14 \mathrm{~cm} \pm 11.3 \mathrm{SD}$ ) and the average distance between trees $=13.31 \mathrm{~m} \pm 3.4 \mathrm{SD}$. The length of the branches was also highly variable, ranging from 85 and $195 \mathrm{~cm},(\bar{x}=127.9 \mathrm{~cm} \pm 21.8 \mathrm{SD})$ and the diameter varied between 2.0 and $4.8 \mathrm{~cm}(\bar{x}=3.2 \mathrm{~cm} \pm 0.7 \mathrm{SD})$.

Branches were cut off approximately $20 \mathrm{~cm}$ below the pupation lodge, which is easily recognisable by a slight external thickening caused by the internal annular gallery made by the larvae (Rodrigo \& Herranz, 2006). 
TABLE 1. The conditions under which Coraebus florentinus was reared in each of the treatments (T); SD - standard deviation.

\begin{tabular}{lccccccc}
\hline & \multicolumn{5}{c}{ Treatments } & \multicolumn{1}{c}{ Natural conditions } \\
\cline { 2 - 5 } \cline { 2 - 5 } & T1 & T2 & T3 & T4 & T5 & T6 \\
\hline Mean temperature $\left({ }^{\circ} \mathrm{C}\right)$ & $15 \pm 2$ & $20 \pm 2$ & $23 \pm 2$ & $26 \pm 2$ & $28 \pm 2$ & $18.1 \pm 5$ \\
Relative humidity $(\%)$ & $60-65$ & $60-65$ & $60-65$ & $60-65$ & $60-65$ & $43.9 \pm 12.2$ (SD) \\
\hline
\end{tabular}

For each branch the following data were recorded: basal diameter (below the pupation lodge), length, date of collection, plant species, and the location and orientation of the branch in the top of each tree. Once defoliated and cut to a length of approximately $40 \mathrm{~cm}$, each branch was individually stored in breathable bags for transport to their final location. In the laboratory, the branches were kept in the bags of plastic breathable mesh, tightly sealed, labelled and randomly distributed into the six experimental groups. Five of these groups were placed in growth chambers, which were maintained at different temperatures ranging from 15 to $28^{\circ} \mathrm{C}$ (Table 1).

The relative humidity in each of the growth chambers ranged between $60-65 \%$, which is similar to the average humidity in the study area during the period April to July (http://www. juntadeandalucia.es/agriculturaypesca/ifapa). The sixth group was kept outside under natural environmental conditions and was the control group. Temperature and humidity that these branches were exposed to were recorded using a portable thermo-hygrometer (Table 1). Because C. florentinus interrupts sap flow, which causes the branches to dry out, the use of pruned branches is unlikely to affect the results. The endophytic life of the preimaginal stages of this insect suggests that light is not a limiting factor in their development; thus, all six treatments were kept in constant darkness.

The branches were inspected every two days to record the time and percentage emergence. The experiment ran from 15 April to 31 July, which is the period over which adults of this species emerge in the field (Jour et al., 2009). At the end of the study, branches from which no adults emerged were examined to confirm the presence of an insect and determine its stage of development.

The following stages were differentiated (Stehr, 1983; Gullan \& Crauston, 1998): (a) Prepupa (or pharate pupae): non-feeding, non-mobile last instar, occurring between the larval and pupal stages (b) Pupa (or pharate adult), (c) Dead imago: fully developed dead adult, which has failed to emerge from the pupal lodge, and (d) Viable imago: living, newly emerged adult (teneral).

For each treatment, the number of individuals in the different stages of development and the average duration of the pupal stage were recorded and the percentage survival was calculated.
Percentage emergence was defined as the percentage of the specimens that reached the adult stage (viable and dead). Percentage survival was defined as the percentage of viable imago recorded in each treatment. For overall population growth, percentage survival is the most significant parameter; nevertheless, the percentage emergence indicates whether all of the adults managed to emerge from the pupal lodge.

In order to test the differences in the time to emergence in the different treatments factorial analyses of variance (ANOVA) was applied to the data for each treatment. The Shapiro-Wilk and Levene tests were used to assess the normality (Zar, 1984). To identify differences between treatments the Tukey-Kramer post-hoc test was used.

Relationships between temperature/percentage survival, temperature/percentage emergence and temperature/time to emergence were assessed: if the scatter plot of data fit a linear function, the respective linear regression equation was calculated and used as a predictive model. When the distribution data fit an exponential function, a logarithmic transformation of the $y$-axis was performed to obtain a regression line (Zar, 1984). Partial correlations between time/percentage emergence and time/percentage survival both controlled for temperature were also calculated.

Calculations were performed using SP statistical software (SPSS Inc., 2002).

\section{RESULTS}

\section{Relationship between stage of development reached and temperature}

From data in Table 2, it can be stated that below $20^{\circ} \mathrm{C}$ (T1) less than $30 \%$ of the larvae developed beyond the pre-pupal stage and no adults emerged from the pupae. The results for treatments $\mathrm{T} 2$ and $\mathrm{T} 3$ indicate that between 20 and $23^{\circ} \mathrm{C}$ only $4 \%$ of the larvae completed their development. However, although the number of larvae reaching the pupal stage increased with increase in temperature, development stopped before the emergence of adults. Between 26 and $28^{\circ} \mathrm{C}$ (T4 and T5) the average larval mortality was nearly half that recorded in $\mathrm{T} 1$ but

TABLE 2. Number of Coraebus florentinus prepupae, pupae, dead adults and live adults recorded in each treatment (T). Percentage emergence (\%), survival (\%) and developmental time (mean, maximum and minimum) recorded at each treatment; SD - standard deviation; $n=25$.

\begin{tabular}{lcccccc}
\hline Treatments & $\mathrm{T} 1$ & $\mathrm{~T} 2$ & $\mathrm{~T} 3$ & $\mathrm{~T} 4$ & $\mathrm{~T} 5$ & $\mathrm{~T} 6$ \\
Mean temperature ${ }^{\circ} \mathrm{C}$ & $15 \pm 2$ & $20 \pm 2$ & $23 \pm 2$ & $26 \pm 2$ & $28 \pm 2$ & $18.1 \pm 5$ \\
\hline Number of prepupae & 18 & 16 & 11 & 9 & 9 & 9 \\
Number of pupae & 7 & 5 & 9 & 6 & 3 & 11 \\
Number of dead imagos & 0 & 3 & 4 & 4 & 0 & 0 \\
Number of viable imagos & 0 & 1 & 1 & 6 & 13 & 5 \\
Percentage emergence (\%) & 0 & 16 & 20 & 40 & 52 & 20 \\
Percentage survival (\%) & 0 & 4 & 4 & 24 & 52 & 20 \\
Mean duration of development (days) \pm SD & - & 57 & 48 & $29 \pm 10.7$ & $28.46 \pm 5.3$ & $46.2 \pm 9.7$ \\
Minimum time required for development (days) & - & 57 & 48 & 15 & 20 & 32 \\
Maximun time required for development (days) & - & 57 & 48 & 46 & 36 & 57 \\
\hline
\end{tabular}


remained approximately $36 \%$ despite the progressive increase in temperature. This percentage is similar to that recorded in the outside (environmental conditions) treatment (T6). The change in the number of pupae showed two clear trends: (i) the number of individuals that achieved this state increased with temperature and (ii) the percentage of pupae that did not give rise to adults decreased as temperature increased. At the end of development, the thermal conditions also affected the viability of imagos; at temperatures near $25^{\circ} \mathrm{C}, 60 \%$ of the imagos were viable, and the percentage increased to $100 \%$ at $28^{\circ} \mathrm{C}$.

\section{Relationship between temperature and percentage emergence and survival}

The scatter plot of percentage emergence at different temperatures was transformed to a simple-linear model adjusted to a simple-linear distribution model, the regression line of which is shown in Fig. 2.

With the parameter estimates $(\mathrm{a}=-61.445$ and $\mathrm{b}=$ 3.886) of the linear regression equation, one can predict that, for an increase of $1{ }^{\circ} \mathrm{C}$ in temperature, the emergence rate increased on the order of $3.89 \%$ within the thermal range of $15-28^{\circ} \mathrm{C}$.

The scatter plot of the relationship between percentage survival and temperature indicated an exponential function, which was transformed to a significant linear relationship by log-transforming the values on the y-axis (Fig. 3), which can then be used to predict possible changes in populations of $C$. florentinus caused by increases in ambient temperature.

\section{Relationship between temperature and the duration of the prepupal-adult phase}

Thermal conditions affected not only the percentage survival of immature stages but also their duration (Table 2). Indeed, the graphical representation of the duration (in days) of the interval between the prepupa and the imago at the different treatments, including those reared under

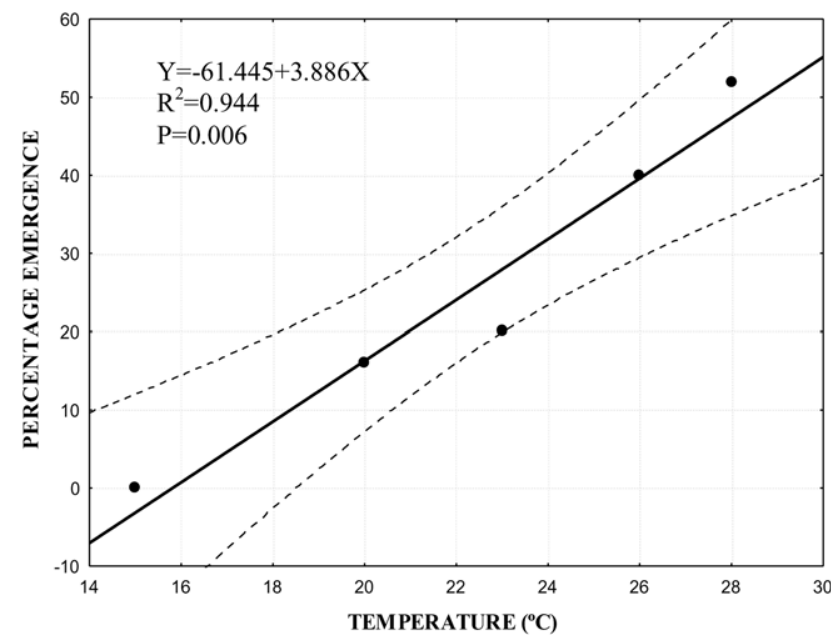

Fig. 2. Simple-linear regression that fits the relationship between percentage emergence of Coraebus florentinus and mean temperature recorded in each treatment.

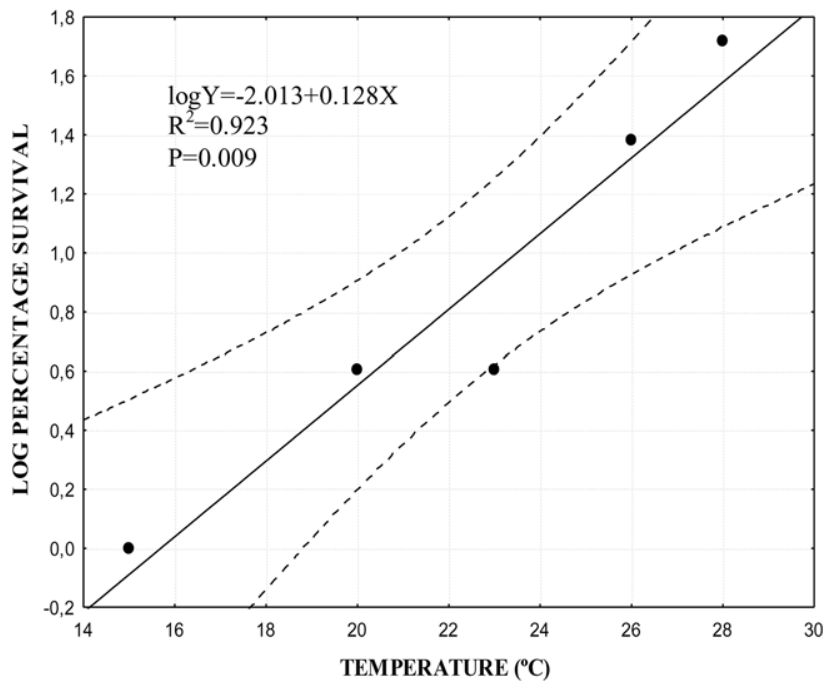

Fig. 3. Simple-linear regression that fits the relationship between log-transformed percentage survival of Coraebus florentinus and mean temperature recorded in each treatment.

more natural conditions, indicated differences (Fig. 4). In the cases in which only one individual completed development (as in T2 and T3) the data were not compared statistically. The differences in time (average duration) between T4/T6 and T5/T6 were significant $(\mathrm{P}=0.004$; $\mathrm{P}$ $=0.001$, respectively; $\alpha=0.05)$. In contrast, the ANOVA was not significant when comparing T4 and T5 treatments $(\mathrm{P}=0.989 ; \alpha=0.05)$. There is a linear relationship between duration of development and temperature (Fig. 5).

In addition, the calculations of the partial correlation between time and emergence controlled for temperature and survival were $r=-0.6647$ and $r=-0.6930$, respectively. Both coefficients confirm that the highest rates of emergence and survival coincided with shorter development times when the treatments were conducted under higher temperatures.

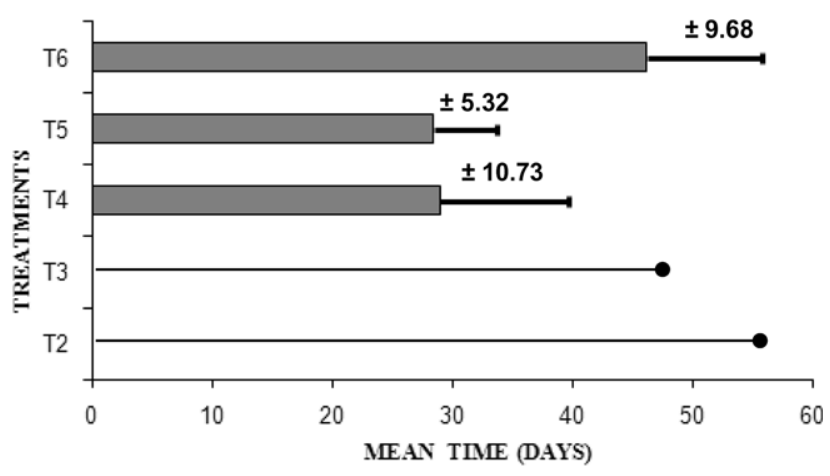

Fig. 4. The mean developmental time (in days) of Coraebus florentinus recorded in the different treatments. The average temperatures in $\mathrm{T} 2, \mathrm{~T} 3, \mathrm{~T} 4, \mathrm{~T} 5$ and $\mathrm{T} 6$ treatments were $20 \pm$ $2^{\circ} \mathrm{C}, 23 \pm 2^{\circ} \mathrm{C}, 26 \pm 2{ }^{\circ} \mathrm{C}, 28 \pm 2^{\circ} \mathrm{C}$ and $18.1 \pm 5^{\circ} \mathrm{C}$, respectively. The standard deviation is given for treatments 4,5 and 6 but not treatments 2 and 3 for each of which there is only one result. 


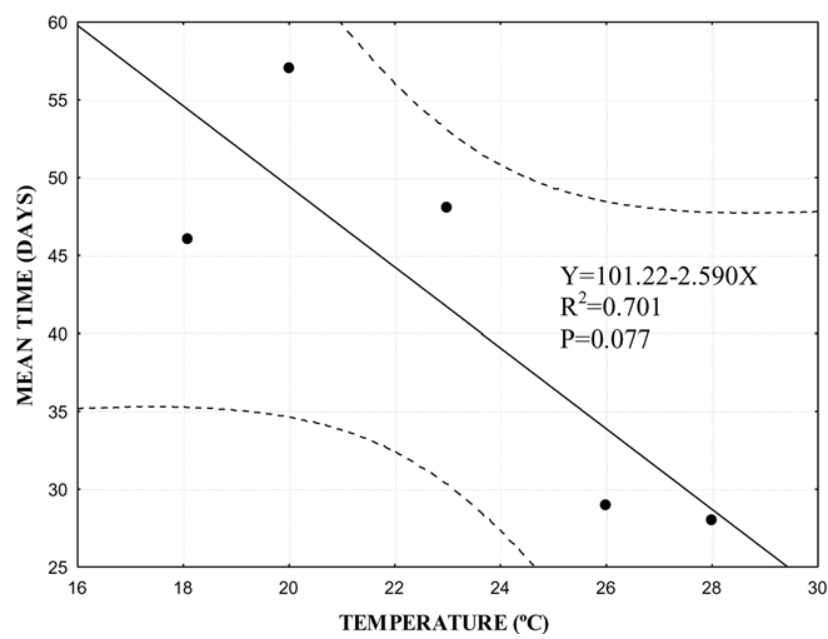

Fig. 5. Simple-linear regression that fits the relationship between mean developmental time of Coraebus florentinus and mean temperature recorded in each of the treatments.

\section{DISCUSSION AND CONCLUSIONS}

Organisms experience seasonal fluctuations in physical and biotic factors and in order to survive, their development, reproduction and population dynamics must adapt accordingly to these environmental fluctuations. The responses of insects to climate change are complex and diverse and depend on their type of life cycle and their ability to adapt, among other factors. In the literature there are many studies on the direct effect of temperature on insect life cycles (this information is partially summarised in Bale et al., 2002). In agreement with the findings of these studies, temperature is identified as a dominant abiotic factor affecting the life history strategies of many phytophagous insects, by inducing changes in rates of development, voltinism, population density, the extent of host plant exploitation and local and geographical distribution. The prediction of the responses of insects to thermal changes is largely based on studies of phytophagous species (i.e. Strathdee \& Bale, 1995; Williams \& Liebhold, 1995; Hodkinson \& Bird, 1998; Hodkinson et al., 1999). Nevertheless, there is no information on the reproductive biology of $C$. florentinus, a potential pest of Quercus species, which are the main component of the Mediterranean mixed forests.

There are, however, studies on the thermal tolerance of other Buprestidae. For example, Myers et al. (2009) found that the survival of the emerald ash borer (Agrilus planipennis Fairmaire) varied with temperature and that its larvae and pupae are capable of surviving temperatures in the range $50-60^{\circ} \mathrm{C}$ for $30-60 \mathrm{~min}$. In addition, Malagón (1989), Malagón et al. (1990) and Marannino \& Lillo (2007) record the effect of some abiotic factors on the reproductive biology of the flat-headed root-borer Capnodis tenebrionis L. (Coleoptera: Buprestidae).

The studies on other species of Buprestidae (Agrilus sinuatus Olivier and A. sulcicollis Lacordaire) reveal that their geographical distributions have changed significantly, some of which may be related to climate change (Alexander, 2003).
This lack of information led us to include the effect of temperature on the development of C. florentinus as a goal in a wider research project that aims to study the effects of wood-borer beetles on species of Quercus in the south of the Iberian Peninsula. Because C. florentinus is a heliophilous and thermophilous insect (Cobos, 1986; Verdugo, 2005), we hypothesised that it would benefit from an increase in temperature. This study did not examine the thermal response of early instars (larva) because infestation by this insect can only be detected after the larvae reach the last stage and their feeding causes the drying out of the branches (see introduction).

Our results on percentage emergence and survival and the duration of development clearly support our hypothesis that temperature affects the post-larval development of $C$. florentinus by increasing percentage survival and shortening developmental time.

In the low temperature treatments $\left(<26^{\circ} \mathrm{C} ; \mathrm{T} 1, \mathrm{~T} 2\right.$ and T3) fewer adults emerged and they needed longer to complete their development than in the T4 and T5 treatments.

Furthermore, a linear extrapolation of the relationship between percentage emergence and temperature indicate a potential increase of $3.89 \%$ for every increase of one degree in temperature. This effect was even more pronounced for percentage survival. Using the predictive model obtained for this parameter, percentage survival increases by $1.22 \%$ when temperature is increased from 20 to $21^{\circ} \mathrm{C}$ and approximately by $10 \%$ when it is increased from 27 to $28^{\circ} \mathrm{C}$. Our results also suggest that there are no differences in the way how prepupae and pupae respond to temperature.

There is a negative linear relationship between the duration of the pupa to adult stage and temperature $(\mathrm{P}=$ $0.077, \alpha=0.1$ ), which indicates that for each degree increase in temperature (over the range of temperatures used), the duration is reduced by 2.59 days. Individuals reared at a constant temperature of $20^{\circ} \mathrm{C}$ required 1.74 times as many days to advance beyond this stage than those kept at $25^{\circ} \mathrm{C}$.

In contrast with the results obtained from laboratory and environment (control) treatments, temperature showed a positive effect on development. The emergence rates in the $\mathrm{T} 4$ and $\mathrm{T} 5$ treatments were noticeably higher than under outside conditions (T6). However, the survival rates were similar between $\mathrm{T} 4$ and $\mathrm{T} 6$, and the highest survival rates occurred with the highest temperatures (T5). Nevertheless, the survival recorded in the control treatment, which experienced natural environmental conditions, was lower than those cited in some recent technical reports (HQAB, 2007, 2008), although the duration of the prepupa to adult stage is similar. This inconsistency may be explained in terms of the climate recorded in the spring of 2009 (Table 1), when the average temperature was unusually low $\left(21.9^{\circ} \mathrm{C}\right.$; http://www.juntadeandalucia. es/agriculturaypesca/ifapa).

As temperature seems to markedly affect percentage emergence, cool springs are likely to be unfavourable for this species. In contrast, warm periods are likely to facilitate increases in abundance. As currently the main tech- 
nique for controlling this pest is to remove branches before the emergence of the adult beetle (Evans et al., 2004), our results could have a clear and practical application in determining the best time to prune the infested branches.

Studies on the effect of climate change on the distribution of different species of Iberian trees (Benito et al., 2008) predict that typical Mediterranean species such as $Q$. suber and $Q$. ilex may undergo significant reduction in their distribution in the future. As the damage caused by C. florentinus is predicted to increase with increase in temperature it is important to develop monitoring programs in areas affected by C. florentinus and to apply scheduled management techniques that ensure the control of this species.

We did not monitor adults after emergence to determine other factors that might also affect the evolution of this species, such as the effect of an increase in temperature on longevity or fecundity, as occurs in other species of buprestids (A. planipennis) (Myers et al., 2009). Simulation experiments of the effect of climate change on aphid species indicate that with increase in temperature, they are likely to become more abundant, but the populations will be less stable (Zhou et al., 1997). On the other hand, in some insects species, including C. florentinus, individuals may develop faster at higher temperatures, and survival may even be enhanced, but some of these insects consequently have lower adult weights and fecundity (Bale et al., 2002), which could adversely affect their abundance.

In summary, despite the clear influence of temperature on the development of the preimaginal stage of C. florentinus, additional trials are required to accurately determine future trends in C. florentinus populations.

ACKNOWLEDGEMENTS. We would like to thank ACUAVIR (Environmental Ministry, Government of Spain) for financially supporting this research.

\section{REFERENCES}

Alexander K. 2003: Changing distributions of Cantharidae and Buprestidae within Great Britain (Coleoptera). In Reemer M., van Helsdingen P.J. \& Kleukes R.M.J.C. (eds): Proceedings of the 13th International Colloquium of the European Invertebrate Survey. European Invertebrate Survey, Leiden, pp. 87-91.

Arnáiz L., Bercedo P. \& De Sousa A.J. 2002: Corología de los Bupréstidos de la Península Ibérica e Islas Baleares (Coleoptera). Bol. Soc. Entomol. Aragon. 30: 37-80.

Ayres M.P. \& Lombardero M.J. 2000: Assessing the consequences of global change for forest disturbance from herbivores and pathogens. Sci. Total Environ. 262: 263-286.

Bachiller P., Cadahia D., Ceballos G., Ceballos P., Cobos J.M., Cuevas P., Dafauce C., Davila J., González J.R., Hernández R., Ledesma L., Mallen J.M., Molina J., Montoya R., Neira M., Obama E., Riesgo A., Robedo F., Romanyk N., Rupérez A., Sánchez A., Soria S., Toimil F.J. \& Torrent J.A. 1981: Plagas de Insectos en las masas forestales españolas. Ministerio de Agricultura, Pesca y Alimentación, 254 pp.

Balachowsky A.S. 1962: Entomologie Apliqueé à l'Agriculture. Vol. 1. Coléoptères. Masson et Cie, Paris, pp. 148-151.
Bale J.S., Masters G.J., Hodkinson I.D., Awmack C., Bezemer T.M., Brown V.K., Butterfield J., Buse A., Coulson J.C., Farrar J., Good J.E.G., Harrington R., Hartley S., Jones T.H., Lindroth R.L., Press M.C., Symrnioudis I., Watt A.D. \& WhitTAKer J.B. 2002: Herbivory in global climate change research: direct effects of rising temperature on insect herbivores. Glob. Change Biol. 8: 1-16.

Benito Garzón M., Sánchez de Dios R. \& Sainz Ollero H. 2008: Effects of climate change on the distribution of Iberian tree species. Appl. Veg. Sci. 11: 1-10.

Buse A. \& Good J.E.G. 1996: Synchronization of larval emergence in winter moth (Operophtera brumata L.) and budburst in pedunculate oak (Quercus robur L.) under simulated climate change. Ecol. Entomol. 21: 335-343.

Ceballos G. 1974: Elementos de Entomología General. Escuela Técnica Superior de Ingenieros de Montes, Sección de Publicaciones, Madrid, $330 \mathrm{pp}$.

Cecconi G. 1924: Manuale de Entomologia Forestale. Tp. Seminario, Padova, 680 pp.

Cobos A. 1986: Fauna Ibérica de Coleópteros Bupréstidos. Consejo Superior de Investigaciones Científicas, Madrid, 364 pp.

Cowling R.M., Rundel P.W., Lamont B.B. \& Arroyo M.K. 1996: Plant diversity in Mediterranean-climate regions. Trends Ecol. Evol. 11: 362-366.

DEFRA (Department for Environment, Food and Rural Affairs) 2010: Natural Environment, Adapting to Climate Change.

Evans H.F., Moraal L.G. \& Pajares J.A. 2004: Biology, ecology and economic importance of Buprestidae and Cerambycidae. In Lieutier F., Day R.K., Battisti A., Gregoire J.C. \& Evans F.H. (eds): Bark and Wood Boring Insects in Living Trees in Europe, a Synthesis. Kluwer Academic Publishers, Dordrecht, pp. 447-474.

Fernández de Cordova J. \& Cabezuelo P. 1995: La "seca de ramillas" o "banderas" de la encina (Coroebus florentinus Herbst.). Distribución biológica y lucha mecánica en la provincia de Córdoba. [The dry of the branches or "flags" of the oaks (Coroebus florentinus Herbst.). Biological distribution and mechanical control in the province of Córdoba.] Phytoma España 71: 31-37.

Freer-Smith P.H., Broadmeadow M.S.J. \& Lynch J.M. 2007: Forest and climate change: the knowledge-base for action. In Freer-Smith P.H., Broadmeadow M.S.J. \& Lynch J.M. (eds): Forestry and Climate Change. $\mathrm{CAB}$ International, Wallingford, pp. 7-15.

Gea-Izquierdo G., Martín-Benito D., Cherubini P. \& Cañellas I. 2009: Climate-growth variability in Quercus ilex West Iberian open woodlands of different stand density. Ann. For. Sci. 66: $802-812$.

Gemeno C. 2007: Memoria de trabajos, parte correspondiente a la Universitat de Lleida sobre la Encomienda de Gestión DGB-CSIC sobre control biorracional de plagas del Género Coraebus. [Report of the University of Lleida on the Management Recommendations for a Bio-rationale Control of the Coraebus Pests.] Ministerio de Medio Ambiente y Medio Rural y Marino.

Goidanich A. 1954: Enciclopedia Agraria Italiana. Vol. 2. Ramo Editoriale degli Agricoltori, Stabilimento Tipografico R.E.d.A.

Gómez-Campo C. \& Malate-Béliz J. 1985: The Iberian Peninsula. In Gómez-Campo C. (ed.): Plant Conservation in the Mediterranean Area. Junk, Dordrecht, pp. 47-71.

Gullan P.J. \& Crauston P.S. 1998: The Insects: An Outline of Entomology. Chapman \& Hall, 504 pp. 
Hodkinson I.D. \& BIRD J. 1998: Host specific insect herbivores as sensors of climate change in Arctic and alpine environments. Arctic Alpine Res. 30: 78-83.

Hodkinson I.D., Bird J., Miles J.E., Bale J.S. \& Lennon J.J. 1999: Climatic signals in the life histories of insects: the distribution and abundance of heather psyllids (Strophingia spp.) in the UK. Funct. Ecol. 13: 83-95.

HQAB 2007: Memoria de trabajos realizados para el control biorracional de plagas del género Coraebus. Encomienda de [Report of bio-rational control of Coraebus genus pests.] Gestión Dirección General para la Biodiversidad-CSIC. General Management of Biodiversity-CSIC.

HQAB 2008: Memoria de trabajos realizados para el control biorracional de plagas del género Coraebus. Encomienda de [Report of bio-rational control of Coraebus genus pests.] Gestión Dirección General para la Biodiversidad-CSIC. General Management of Biodiversity-CSIC.

Jurc M., Bojovic S., Komjanc B. \& KrČ J. 2009: Xylophagous entomofauna in branches of oaks (Quercus spp.) and its significance for oak health in the Karst region of Slovenia. Biologia 64: 130-138.

Malagón J. 1989: Bioecología de Capnodis tenebrionis L. (Col. Buprestidae) e influencia de ciertos factores abióticos sobre sus estados inmaduros en el momento de la eclosión del huevo y su penetración en huéspedes de interés agrícola. [Bio-ecology of Capnodis tenebrionis L. (Col. Buprestidae) and the Effect of Certain Abiotic Factors on their Immature Stages at the Time of Egg Hatching and Penetration of Agricultural Hosts.] Ph.D. thesis, Polytechnic University of Valencia, Spain.

Malagón J., Garrido A., del Busto T. \& Castañer M. 1990: Influencia de algunos factores abióticos en la oviposición de Capnodis tenebrionis (L.) Coleoptera, Buprestidae. [The effect of some abiotic factors on the oviposition of Capnodis tenebrionis L. (Col. Buprestidae).] Invest. Agrar. Prod. Prot. Veg. 5: 441-446.

Marannino P. \& Lillo E. 2007: Capnodis tenebrionis (L. 1758) (Coleoptera: Buprestidae): Morphology and behaviour of the neonate larvae, and soil humidity effects on the egg eclosion. Ann. Soc. Entomol. Fr. 43: 145-154.

Maresi G. \& SAlvadori C. 2005: Crown conditions and damages in two forest ecosystems in Trentino (Italy). Studi Trent. Sci. Nat. Acta Biol. 81: 253-260.

Médial F. \& Quézel P. 1997: Hot-spots analysis for conservation of plant biodiversity in the Mediterranean Basin. Ann. Missouri Bot. Garden 84: 112-127.

Montoya J.M. 1988: Los Alcornocales. [The Cork-oak Forests.] Ministerio de Agricultura, Pesca y Alimentación, Madrid.

Myers S.W., Fraser I. \& Mastro V.C. 2009: Evaluation of heat treatment schedules for emerald ash borer (Coleoptera: Buprestidae). J. Econ. Entomol. 102: 2048-2055.

Navarro R., Fernández-Cancio A. \& Herranz O. 2007: The vitality of cork and holm oak stands and forests. Report on the Évora Conference meeting.

PARDos J.A. 2006: La contaminación atmosférica y los ecosistemas forestales. Forest Systems 15: 55-70.

Patón D., García-Herrera R., Cuenca J., Galavis M. \& Roig F.A. 2009: Influence of climate on radial growth of holm oaks (Quercus ilex subsp. ballota Desf) from SW Spain. Geochronometria 34: 49-56.

Riba J.M. 2008: Estudio de aspectos biológicos y ecológicos de la culebrilla del corcho Coraebus undatus y de la culebrilla de las ramas Coraebus florentinus. Resultados 2008. [A Study on the Biological and Ecological Aspects of the Cork Pests Coraebus undatus and Coraebus florestinus. Results from
2008.] Acuerdo entre el Departament de Medi Ambient i Habitatge y Joseph M. Riba Flinch, 19 pp.

Rivas J. 2000: Daños causados en encinar por Coraebus florentinus (Col. Buprestidae) e incidencia de sus enemigos naturales en la finca "Las Navas". [Damage Caused by Coraebus florentinus (Col. Buprestidae) in Oak Forest and Incidence of Natural Enemies at the "Las Navas" Farm.] Proyecto Fin de Carrera. E.T.S.I.A.M. Universidad de Córdoba.

Rodrigo R. \& Herranz J.L. 2006: Actas de Reunión del Acuerdo de Encomienda de Gestión entre la Administración General del Estado, Ministerio de Medio Ambiente (Dirección General para la Biodiversidad-DGB) y el Consejo Superior de Investigaciones Cientificas (CSIC) para el control biorracional de plagas del Género Coraebus. [Proceedings of the Meeting for the Bio-rationale Control of the Coraebus pests. Agreement Between the General Administration of the State, Environment Ministry (DGB) and the National Research Council (CSIC).] Ministerio de Medio Ambiente y Medio Rural y Marino, Madrid.

RomanyK N. \& CADAhía D. 1992: Plagas de Insectos en las Masas Forestales Españolas. [Insect Pests in Spanish Forests.] Ministerio de Agricultura Pesca y Alimentación. ICONA. Colección técnica. Segunda edición. Madrid.

Sánchez E., Gallardo C., Gaertner M.A., Arribas A. \& CASTro M. 2004: Future climate extreme events in the Mediterranean simulated by a regional climate model: a first approach. Global Planet. Change 44: 163-180.

SCHAEFER L. 1949: Les Buprestides de France. Le Moult, Paris, $511 \mathrm{pp}$.

Solinas M. 1974: Coroebus florentinus (Herbst) (Col. Buprestidae). Biologia, danni, lotta. Entomologica 10: 141-193.

SORIA F.J. 1990: Estudios biológicos sobre Coroebus undatus (Fabricius) y Coroebus florentinus (Herbst) (Coleoptera, Buprestidae) en alcornocales de Andalucia Occidental. [Biological Studies on the Coroebus undatus (Fabricuis) and Coroebus florentinus (Herbst) (Coleoptera, Buprestidae) in Cork-oaks from Western Andalusia.] PhD. thesis, Universidad de Sevilla.

Soria F.J. \& OCETE M. 1993: Estudios poblacionales sobre Coroebus florentinus (Herbst) (Col. Buprestidae). Bol. San. Veg. Plagas 19: 27-35.

Soria F.J., Villagrán M., Del Tio R. \& Ocete M.E. 1994: Estudios prospectivos de los principales perforadores del alcornoque en la Sierra Norte de Sevilla. [Prospective studies of major oak-borer pests in the Sierra Norte of Seville.] Bol. San. Veg. Plagas 20: 643-651.

SPSS INC. 2002: SPSS 12.0 for Windows Use Manual (version 12.0)

SteHR F.W. 1983: Immature Insects. Vol. 2. Kendall Hunt, Dubuque, 974 pp.

Strathdee A.T. \& Bale J.S. 1995: Factors limiting the distribution of Acyrthosiphon svalbardicum (Hemiptera: Aphididae) on Spitsbergen. Polar Biol. 15: 375-380.

Tiberghien G. 1974: Les collections entomologiques du Museum d'Histoire Naturelle de Bayonne. Bull. Cent. Etud. Rech. Sci. 10: 277-283.

Verdugo A. 2005: Fauna de Bupréstidos de la Península Ibérica y Baleares. Arganda, Barcelona, $350 \mathrm{pp}$.

Walther G.R., Post E., Convey P., Menzel A., Parmesank C., Beebee T.J.C., Fromentin J.M., Hoegh-Guldberg O. \& BairLEIN F. 2002: Ecological responses to recent climate change. Nature 416: 389-395.

WiLliams D.W. \& LiebHold A.M. 1995: Herbivorous insects and global change-potential changes in the spatial-distribution of forest defoliator outbreaks. J. Biogeogr. 22: 665-671. 
Zar J.H. 1984: Biostatistical analysis. Prentice Hall, New Jersey, $663 \mathrm{pp}$.

Zhou X., Perry J.N., Woiwod I.P., Harrington R., Bale J.S. \& CLARK S.J. 1997: Temperature change and complex dynamics. Oecologia 112: 543-550.

Zochi R. 1953: Una eccezionale infestazione di Coroebus fasciatus Villiers in Toscana. Redia 38: 163-168. http://www.juntadeandalucia.es/agriculturaypesca/ifapa. Estaciones Agroclimáticas. Instituto de Investigación y Formación Agraria y Pesquera. Consejería de Agricultura y Pesca. Junta de Andalucía.

Received May 20, 2011; revised and accepted August 30, 2011 